FIU Law Review

Fall 2010

\title{
Reflections on the Doctrinal and Big-Picture Issues Raised by the Constitutional Challenges to the Patient Protection and Affordable Care Act (Obamacare)
}

Vikram David Amar

UC Davis School of Law

Follow this and additional works at: https://ecollections.law.fiu.edu/lawreview

Part of the Other Law Commons

Online ISSN: 2643-7759

Recommended Citation

Vikram D. Amar, Reflections on the Doctrinal and Big-Picture Issues Raised by the Constitutional Challenges to the Patient Protection and Affordable Care Act (Obamacare), 6 FIU L. Rev. 9 (2010).

DOI: https://dx.doi.org/10.25148/lawrev.6.1.5

This Article is brought to you for free and open access by eCollections. It has been accepted for inclusion in FIU Law Review by an authorized editor of eCollections. For more information, please contact lisdavis@fiu.edu. 


\title{
Reflections on the Doctrinal and Big-Picture Issues Raised by the Constitutional Challenges to the Patient Protection and Affordable Care Act (Obamacare)
}

\author{
Vikram David Amar*
}

The challenges to the federal healthcare statute enacted last year, the Patient Protection and Affordable Care Act (PPACA or Act), ${ }^{1}$ that are currently winding their way through the federal courts - and the few decisions that have embraced these challenges so $\operatorname{far}^{2}-$ appear to suffer from a problematic blend of doctrinal hypertechnicality, theoretical imprecision, and (understandable but misplaced) fear of an all-powerful Congress. None of this is to say it will be impossible for any of these challenges ultimately to succeed. Instead, it is to say that any such success would either be revolutionary (in the way that Justice Clarence Thomas' desire to return to nineteenth century cases concerning the scope of federal power would, if implemented, completely upend the current constitutional convention), ${ }^{3}$ or it would be tailored to reach a particular result on a particular contentious issue (in the way Bush v. Gore is viewed by many as a ruling good for only one day and one election).

To date, the prominent challenges to the PPACA sound, as a matter of law if not political rhetoric, in federalism rather than a rights-based libertarianism. As anyone following these litigations knows, the focal point for the constitutional attacks has been the so-

\footnotetext{
Associate Dean for Academic Affairs and Professor of Law, UC Davis School of Law. I thank the organizers of the Florida International University School of Law for inviting my participation in the symposium on the healthcare law challenges held in Florida in late 2010. Although I was unable to attend the event in person, I have profited from reading the papers of some of the other presenters.

1 Patient Protection and Affordable Care Act, Pub. L. No. 111-148, 124 Stat. 119 (2010), amended by the Health Care and Education Reconciliation Act of 2010, Pub. L. No. 111-152, 124 Stat. 1029 (2010) (codified in scattered sections of 21, 25, 26, 29, and 42 U.S.C.).

2 See Florida v. U.S. Dep't of Health \& Human Servs., Nos. 11-11021, 11-11067, 2011 WL 3519178 (11th Cir. Aug. 12, 2011); Virginia v. Sebelius 728 F. Supp. 2d. 768 (E.D. Va. 2010); Florida v. U.S. Dep't of Health and Human Servs., No. 3:10-cv-91-RV/EMT, 2011 WL 285683 (N.D. Fla. Jan. 31, 2011) (N.D. Fla. 2011).

See, e.g., Gonzales v. Raich, 545 U.S. 1, 57-61 (2005) (Thomas, J., dissenting).

531 U.S. 98 (2000).
} 
called individual mandate provision of the federal statute - the provision that requires individuals to procure basic health insurance lest they be obligated to pay a prescribed amount of money into the federal Treasury. ${ }^{5}$ More specifically, the plaintiffs challenging the Act deny that Congress enjoys any enumerated power to impose such a mandate. ${ }^{6}$

The plaintiffs seem to concede that Congress ordinarily has great latitude to regulate matters that bear on the national economy, even when the things being regulated occur entirely intrastate. And all aspects of the healthcare system, regardless of where the key actors and institutions happen to be physically located, are undeniably significant and interconnected components of a national supply and demand market for healthcare goods and services that comprises a very large portion of America's gross domestic product. So, generally speaking, congressional reform relating to healthcare insurers, consumers and providers - because these insurers, consumers and providers are so tightly linked across the several states - does not run afoul of the Tenth Amendment.

Apparently recognizing this overriding reality - that Congress' end with respect to healthcare reform is "legitimate," as the Court famously required in McCulloch v. Maryland ${ }^{7}$ - the plaintiffs attack the congressionally-chosen means, i.e., the mandate, as constitutionally improper. Plaintiffs do not assert that the individual mandate fails to further Congress" end and is thus not "plainly adapted" to it in that sense ${ }^{8}$ instead, the challengers argue that the means utilized by Congress violate another (until now unstated) requirement for Commerce Clause regulation, that Congress refrain from regulating "inactivity." Implicit in the plaintiffs' argument is that compelling people who are refraining from the procurement or purchase of health insurance is not, again to use the words of McCulloch, "consist[tent] with the letter and spirit of the constitution," at least as far as Commerce Clause power is concerned. It thus becomes crucial to examine this requirement upon which the challengers insist - that Congress confine itself to regulating preexisting active conduct by individuals, as opposed to regulating individuals' decisions not to purchase health insurance.

5 Patient Protection and Affordable Care Act $\S 1501$ (requiring, subject to minor exceptions, all citizens and others lawfully residing in the United States to carry a specified minimal level of health insurance coverage or pay money to the Treasury).

6 See Virginia v. Sebelius 728 F. Supp. 2d. 768 (E.D. Va. 2010); Florida v. U.S. Dep't of Health and Human Servs., No. 3:10-cv-91-RV/EMT, 2011 WL 285683 (N.D. Fla. Jan. 31, 2011) (N.D. Fla. 2011).

7 McCulloch v. Maryland, 17 U.S. (4 Wheat.) 316, 421 (1819).

$8 \quad$ Id.

$9 \quad I d$. 


\section{THE LEGAL THEORIES}

A. The Source of the Proffered Distinction Between Regulation of Activity and Compulsion of Activity

Challengers to the PPACA derive their so-called activity requirement a few different ways. First, they point out that the "federal government has never attempted to regulate inactivity, or a person's mere existence within our Nation's boundaries, under the auspices of the Commerce Clause." ${ }^{\prime \prime}$ Second, they sometimes argue that the grant of Congress to "regulate commerce" textually presupposes that some active commerce exists on the part of the regulated person(s) before Congress has authority to step in and regulate. Finally, they seem to rely on the extent to which the Supreme Court itself, in the trio of major Commerce Clause cases over the past 15 years, has spent time and energy analyzing whether that which Congress has chosen to regulate was economic/commercial "activity," before deferring to Congress' determination that the aggregated effects of the regulation in question influence interstate commerce sufficiently to permit federal legislation. ${ }^{11}$

Each of these sources of an activity requirement is problematic. As to the first, there is an inadequate explanation of why novelty equates with unconstitutionality. To be sure, if a congressional practice is deeply rooted in history, especially history dating back to the founding, then such a history may tend to cut in favor of the law's constitutionality. Laws without such statutory precedent may thus lack one argument in their favor, ${ }^{12}$ but of course all congressional laws - even novel ones - come to the federal courts bearing a presumption of constitutionality. ${ }^{13}$ And the challengers must do more than characterize a law as newfangled to defeat that presumption.

More importantly, the novelty objection, such as it is, dissolves when we expand our focus to include all congressional regulation and not just regulation under the Commerce Clause. Tellingly, challengers to the Act offer no explanation for why an activity requirement should be engrafted onto the Commerce Clause in particular, if no

10 Thomas More Law Ctr. v. Obama, 720 F. Supp. 2d 882, 891 (E.D. Mich. 2010).

11 See Virginia v. Sebelius, 728 F. Supp. 2d. 768,771-72, 778-79 (E.D. Va. 2010).

$12 C f$. New York v. United States, 505 U.S. 144, 177 (1992) (noting how the "take title" provision of the federal statute at issue "appears to be unique[ ] [in that] [n]o other federal statute has been cited which offers a state government no option other than that of implementing legislation enacted by Congress.").

13 Even the district court judge in Virginia v. Sebelius purported to concede this point. See Sebelius, 728 F. Supp 2d. at 774 ("[T]he Secretary correctly asks the Court to be mindful that it must presume the constitutionality of federal legislation."). 
such requirement encumbers congressional lawmaking discretion more generally. If Congress is authorized to pass, and has in fact passed, laws regulating inactivity - that is, laws mandating affirmative activity - under other of its enumerated powers, such a practice would tend to argue against constitutional recognition of an activity requirement, unless the other fonts of federal power under which inactivity has been regulated can be shown to be textually, historically, or structurally distinguishable from the Commerce Clause. Thus, the fact that Congress can mandate military, militia, and jury service, as well as participation in the census ${ }^{14}$ - even though the Tenth Amendment and federalism principles, the same principles that undergird limits on congressional power under the Commerce Clause, insist on enumerated authority for these regulations - would seem to require more of an explanation than the challengers to the Act have thus far offered.

It would not do to suggest that these other, permissible, congressional mandates do not involve compelled purchases (as if that mattered). As many have pointed out, early federal militia Acts - laws no one seems eager to question - required would-be militia members, who were doing no more than being, to show up for service outfitted with a minimum prescribed set of equipment, equipment that the individual was responsible for acquiring, that is, affirmatively obtaining, most likely through purchase. For example, the Militia Act of $1792^{15}$ required able-bodied men to become Federal militia members, who were then required to arm themselves with a musket, bayonet and belt, two spare flints, a cartridge box with 24 bullets, and a knapsack. Men owning rifles were required to provide a powder horn, 1/4 pound of gun powder, 20 rifle balls, a shooting pouch, and a knapsack. ${ }^{16}$

Nor does the constitutional text under which the military draft, militia service, jury service, or census participation are mandated explain why affirmative conduct can be required in those realms but not under the Commerce Clause. Article I permits Congress to "raise and support" Armies, but there is nothing in the text of this clause that indicates why mandatory military service is permissible. "Raise and support" could be read to mean "create incentives to voluntarily in-

14 See, e.g., Selective Draft Law Cases, 245 U.S. 366 (1918).

15 Militia Act of 1792, ch. 33, 1 Stat. 271.

16 Eminent domain by the federal government, surely authorized in order to implement other permissible federal objectives, also requires a compelled transaction, depriving the individual of choice over how to spend his resources. Remember, too, that land is unique, so that a forced exchange of land for money leaves the unhappy former landowner less pleased than before the compelled transaction.

17 U.S. CONST. art. I, § 8, cl. 12. 
duce." But the Supreme Court had little trouble holding in 1925 that this clause, combined with the Necessary and Proper clause, permitted Congress to mandate service - to regulate inactivity - because Congress should not be dependent on the inclinations and reluctances of individuals to accomplish Article I's enumerated objectives. ${ }^{18}$

More generally, the word "regulate" does not foreclose compulsion of activity, including compulsion of commercial activity. "Regulate" in modern dictionaries means, among other things, to "direct."19 When we turn to the Constitution itself as a possible dictionary, ${ }^{20}$ we see that it uses the word "regulate" at least sometimes in ways that include a power to mandate activity. The militia in which Congress can compel membership, for example, is referred to as one that is "well[-]regulated" in the Second Amendment. ${ }^{21}$ Congress' power in Article I to "regulate the [v]alue" of money ${ }^{22}$ would seem to permit Congress, under certain circumstances, to require individuals to exchange their currency for something else Congress reasonably believes would provide stability to the monetary system of the country. Congress' power to adopt rules for the "[r]egulation" of the land and naval forces ${ }^{23}$ undeniably allows Congress to mandate activity on the part of otherwise disinclined men and women in the armed forces, when such mandates are reasonably helpful to the national defense. Congress' "[r]egulation[ ]" of the Supreme Court's appellate jurisdiction $^{24}$ would seem to permit Congress to require the Supreme Court to affirmatively act. And "needful Rules and Regulations respecting" federal properties ${ }^{25}$ would, the Court has said, include all those things that states can do under their police powers, ${ }^{26}$ and challengers to the healthcare law do not in their complaints challenge the power of

18 Selective Draft Law Cases, 245 U.S. 366, 378 (1918) (“[A] governmental power which has no sanction to it and which therefore can only be exercised provided the citizen consents to its exertion is in no substantial sense a power.").

19 See, e.g., American Heritage College Dictionary 1172 (4th ed. 2004).

20 See generally Akhil Reed Amar, Intratextualism, 112 HARV. L. REV. 747, 791 (1999) (discussing the utility of using the Constitution itself as a dictionary of sorts).

21 U.S. CONST. amend. II. The Bill of Rights provisions more generally show that when the Constitution refers to conduct, it also means to include the absence of such conduct. The right to freedom of speech includes the freedom not to speak. The right to procreate subsumes the right not to procreate. An argument can be made that just as this is true for rights, so too should it generally be true for powers: the power to regulate commerce includes the power to regulate non-commerce.

22 U.S. CONST. art. I, $\S 8$, cl. 5.

23 U.S. CONST. art. I, $\$ 8$, cl. 14.

24 U.S. CONST. art. III, $\S 2$, cl. 2.

25 U.S. CONST. art. IV, $\$ 3$, cl. 2.

26 See Kleppe v. New Mexico, 426 U.S. 529, 540 (1976) ("[T]he [federal] [g]overnment doubtless has a power over its own property analogous to the police power of the several [s]tates ....") (internal quotations and citations omitted). 
states, such as Massachusetts, to mandate purchase of healthcare, just as states can mandate vaccination and compulsory education under the police power. ${ }^{27}$

The claim I make here is not that the power to regulate commerce always includes the power to mandate commerce, or that all mandates are "necessary and proper" regulations of commerce. But I needn't prove all mandates are permissible; the challengers to the healthcare act are arguing - and have to be arguing - that all mandates (save, I assume, those they can't dispute) are unconstitutional. My point here is only that there is nothing in the text or history of the Constitution, viewed as a whole and examined with specific reference to the power to "regulate," that supports this argument. Regulation can, at least sometimes, take the form of mandates. And so it is incumbent on the challengers to explain why the healthcare law is not one of them. In fact, as I argue below, the PPACA mandate is one of the most natural and defensible kinds of mandates, so that if other regulatory mandates are permissible, this one should be permissible $a$ fortiori.

The final possible source of an anti-mandate, activity requirement, recent Supreme Court cases, does not help PPACA opponents make the kind of required explanation. It is true that in United States v. Lopez ${ }^{28}$ and United States v. Morrison, ${ }^{29}$ in striking down the GunFree Schools Zones Act (GFSZA) and the Violence Against Women Act (VAWA), respectively, the Court highlighted the fact that the subjects of congressional regulation (possession of guns near schools and the commission of gender-motivated violence), did not constitute "economic activity." And in Gonzales v. Raich, ${ }^{30}$ in distinguishing Lopez and Morrison en route to upholding the Controlled Substance Act's (CSA) federal criminalization of all manufacture, sale, distribution, or possession of marijuana, the Court emphasized that the CSA dealt with "economic activity.",31

The question raised by the PPACA challengers' reliance on these cases, however, is whether the Court meant to use the term "economic activity" in the kind of intentional and unyielding way the Act's challengers suggest. In the cases themselves - Lopez, Morrison and

27 See supra note 3 . The fact that states can mandate activity demonstrates that the American law does not, contrary to what some PPACA challengers allege, generally embody a distinction between action and inaction. Sometimes the law forbids compelled action, but there is no general legal, or constitutional, aversion to activity requirements.

28514 U.S. 549, 551, 561 (1995).

29529 U.S. $598,613(2000)$.

30545 U.S. 1 (2005).

31 Id. at 25. 
Raich - the Court's focus was on whether the regulated activity was economic, not whether it was an activity. Would the PPACA challengers pack up and go home had the Court in these cases - as it very well might have done for purposes of those disputes - used the term "economic matters" or "economic decisions" to describe the things Congress has broad latitude to regulate? Or what if the Court had simply said Congress can regulate "economics" under the Commerce Clause? In Raich, Justice Stevens, writing for the majority, said that “[e]conomics' refers to the production, distribution, and consumption of commodities.",32 He wrote that sentence right after he asserted that "[u]nlike those [activities] at issue in Lopez and Morrison, the activities regulated by the CSA [at issue in Raich] are quintessentially economic." $\mathrm{He}$ might have meant to use the noun "economics" to help give meaning to the adjective "economic" in the term "economic activity," and not have intended a relaxation of any independent requirement of activity. Or he might have meant to substitute "economics" for "economic activity" altogether, in which case the question would become whether the mandate provision of the PPACA regulates production, distribution, or consumption of a commodity, regardless of whether that which the mandate regulates is an activity or not.

Indeed, if we give meaning to economic activity by reference to "consumption," in addition to production and distribution (as Raich suggests we should), then individuals who do no more than exist are engaging in the activity of consumption of healthcare in the sense that they benefit from and free ride on the healthcare system's creation and maintenance by the rest of us. The key policy reason Congress created the mandate could easily be seen to be twofold: (1) people without insurance have an incentive to be a freeloader because they know that they will be treated in a healthcare emergency, either because they know that society won't sit idly by and watch them die, or because the condition from which they suffer might be contagious or have other spillover effects threatening the health and safety of other people; and (2) people without insurance have inadequate incentive to deal with small health problems before they become large ones (because they must pay for healthcare treatments out of pocket), and thus they tend to be more dangerous to the rest of us by spreading preventable diseases and/or engaging in potentially dangerous activities on account of pain or disability. These incentive problems are increased greatly by another part of PPACA, the provision that pre-

32 Id. (quoting WEBSTER's THIRD NEW INTERNATIONAL DiCTIONARY 720 (1966)).

33 Id. 
vents health insurance companies from discriminating against persons with so-called preexisting conditions. ${ }^{34}$ Because people know they can purchase insurance after, rather than before, they become seriously ill or injured, they are even more likely to free ride until that acute need arises. If these incentive problems might describe reality, and certainly Congress could and did reasonably believe that they do, then people who decide not to obtain health insurance nonetheless are consuming healthcare in the sense that they benefit by it. ${ }^{35}$ Healthcare, like national defense and democracy, is a public good in this sense, and it is consumed as much by inactivity as by activity.

\section{B. The Elasticity of the Definition of "Activity"}

This last observation points up the difficulty of even defining what activity means for these purposes. Assuming, arguendo, that breathing isn't an activity (because it isn't volitional enough), and freeloading doesn't count as an activity (because it is too passive) and neither of these conclusions is obvious - consider another subject of Commerce Clause regulation that has been upheld by the Court, even by the Court that decided Lopez and Morrison, without much fanfare: discrimination in the buying or selling of goods and services. Congress, under the Commerce Clause, often makes it unlawful to discriminate on the basis of, say, race in the making of contracts. ${ }^{36}$ In his dissent in Morrison, Justice Breyer questioned whether Congress was regulating "economic activity" in these settings, his question being whether discrimination was "economic" or instead was driven by other motives. $^{37}$ I focus here not on whether race discrimination is economic, but rather whether discrimination against certain persons or things is always easily capable of characterization as activity. From one angle, a ban on discrimination poses no problem to the challengers of the healthcare Act, insofar as "the making of contracts" is con-

34 Patient Protection and Affordable Care Act, 42 U.S.C. § 300gg-3 (2011).

35 Another (and related) interesting possibility that co-symposium invitee Gerard Magliocca raises is that self-insurance be considered activity. See Gerard N. Magliocca, The Private Action Requirement 6 FIU L. REV. 1 (2011). And a very plausible argument can be made that since the tax penalty imposed by the Act applies only to people who are obligated to file a tax return, the activity that is being regulated is the activity that triggers the requirement to file a tax return. See Patient Protection and Affordable Care Act of 2010, Pub. L. No. 111-148, § 1501(b), 124 Stat. 119, 242, amended by Health Care and Education Reconciliation Act of 2010, Pub. L. No. 111-152, § 1002(b)(2), 124 Stat. 1029, 1032. If the law requiring people to file tax returns is not an impermissible mandate, then neither is a law requiring people who must file returns to purchase insurance.

36 See 42 U.S.C. $\$ 1981$ (2006).

37 United States v. Morrison, 529 U.S. 598, 658 (2000) (Breyer, J., joined by Stevens, Souter and Ginsburg, JJ., dissenting). 
sidered an activity. But isn't Congress - when it prohibits discrimination - essentially forcing people to engage in transactions that they'd rather not undertake? If a person declines to buy from a seller because the seller is black, an antidiscrimination law, in effect, mandates that he buy. Of course, the technical rejoinder would be that the regulated individual could simply escape the purchase mandate by choosing not to buy at all; it is still a volitional decision he makes about whether to enter into any purchase agreements with anyone at all. But is this rejoinder persuasive? Do people really have a choice not to buy food, or shelter, or clothing? And in any event, would challengers to the PPACA be satisfied if Congress rewrote the mandate in antidiscrimination terms? "No citizen shall discriminate, in the goods and services he purchases, against healthcare policies offered by insurers." In other words, if you buy anything, you've got to buy healthcare.

The ease with which Congress could rewrite the mandate provision to satisfy any activity requirement that any court imposed raises, I think, some big questions about why any such requirement should exist. For example, in addition to styling the mandate in nondiscrimination terms, Congress could make use of the so-called "jurisdictional element" device the Court has spoken favorably of in Lopez and Morrison." Imagine Congress had said: "People who have not purchased healthcare may not enter into any workplace or place of business open to the public, and may not travel on roadways that connect to interstate transportation systems, else they pay a fee to the federal Treasury." Would this be any less of a mandate in reality? Do people have a choice not to interact with other people, or use roads and channels of transportation and commerce? And yet, this kind of a law would likely be upheld under current doctrine, and even under the plaintiffs' theories. Indeed, the kind of jurisdictional element I describe here is much less gimmicky than others that have been approved, ${ }^{39}$ insofar as the jurisdictional element of interaction with other people captures quite nicely Congress' authentic policy reasons for wanting to mandate healthcare coverage - to reduce the spillover effects that arise when people without insurance have inadequate incentive to take care of themselves and thus place the rest of us in the position of being vulnerable to health and/or economic costs when we interact with them. Surely this jurisdictional element is much more proximately related to the permissible reason Congress is regulating in the healthcare realm than, in the context of Morrison,

38 See Morrison, 529 U.S. at 613 \& n.5.

39 See Morrison, 529 U.S. at 613 n.5. 
was the part of the law that made it a federal crime to cross a state line to inflict gender-motivated violence. The interstate travel really has no logical relationship to any commercial reason Congress might want to regulate gender-motivated violence. ${ }^{40}$

Perhaps an argument could be made that requiring Congress to go through these drafting gymnastics to satisfy an activity requirement would serve federalism values underlying the Tenth Amendment and the doctrine of limited, enumerated federal powers. It's hard to see why that would be so. Sometimes encouraging Congress to make certain findings, or write its statutory text in certain ways, does carry with it the benefit of making Congress contemplate and weigh federalism values and/or put the affected states and American votes on clear notice that Congress is legislating in a way that might alter traditional mixes of federal and state regulatory exercise. ${ }^{41}$ But the salutary procedural benefits that explain, for example, the plain-statement requirements that must be met before direct regulatory restrictions or spending conditions are imposed on state governmental entities, do not seem to argue in favor of redrafting the healthcare mandate provision along the lines suggested above. No one denies that the healthcare Act reflected a substantial new Congressional regulation in the healthcare sector, and no one could deny that the mandate aspect of the law and its effect on individuals and states was fully appreciated, considered, and vetted by Congress. Nor could anyone argue that the mandate provision in particular was not well understood and advertised to the states and the American people; the provision did not, to use Marshall's words in McCulloch again, "steal upon an unsuspecting legislature, and pass unobserved" by either opponents in Congress or among the American electorate. ${ }^{42}$

Given that everybody knew what Congress was requiring and why, the issue should be whether Congress can require it, not the particular words Congress uses to style the requirement.

Before I leave the major Commerce Clause cases and how the doctrinal nuances they embody bear on the PPACA challenges now pending, I should mention that just as the idea of congressional regulation of inactivity may, as challengers allege, be somewhat novel, so too is the idea that such a distinction between activity and inactivity should matter. That is to say, while no Supreme Court opinion may have upheld congressional Commerce Clause regulation of mere "be-

40 Cf. id.

41 See, e.g., Gregory v. Ashcroft, 501 U.S. 452, 461 (1991) (adopting plain-statement rule for laws that subject state governments to federal regulation); South Dakota v. Dole, 483 U.S. 203, 203 (1987) (reiterating plain-statement rule for conditions on state receipt of federal funds).

42 McCulloch v. Maryland, 17 U.S. (4 Wheat.) 316, 402 (1819). 
ing" of the kind found in the mandate, neither has any Supreme Court opinion struck something like this down. Indeed, to the extent that the Court has found occasion to discuss anything coming close to the activity/inactivity distinction in the Commerce Clause realm, the most relevant discussion is not the (perhaps careless) use of the phrase "economic activity" in cases like Lopez, Morrison and Raich, but rather the discussion of the permissibility of congressional regulation in Wickard v. Filburn. ${ }^{43}$ In that case, the Court upheld the limits the federal government placed on a small farmer's wheat acreage against the challenge that the allotment as applied to someone who was not selling wheat into the market lacked enumerated federal power behind it. Although healthcare Act challengers would surely point out that the marketing quota challenged in Wickard prevented the farmer from, as a technical matter, raising crops (an activity), they must also reckon with the Court's quite explicit reasoning for permitting the quota: the creation of new transactions that would ensue because people who couldn't cultivate their own plots would be forced into the market. As the Court observed, "[t]he stimulation of commerce is a use of the regulatory function quite as definitely as prohibitions or restrictions thereon." ${ }^{44}$ Earlier cases had abandoned any distinction between regulation of commerce and prohibition of it. ${ }^{45}$ Wickard, fully in keeping with the other uses of the word "regulate" in the Constitution described above, makes clear that the commerce that Congress can regulate need not have preexisted before the congressional regulation in question; Congress can regulate commerce by "creating" commerce, by setting conditions that generate transactions that never otherwise would have occurred. If Congress can force transactions indirectly by prohibiting self-help, why can it not do so more directly by openly requiring the transactions themselves. Indeed, the case for congressional regulation seems even stronger in healthcare than in Wickard, insofar as the farmer in Wickard wasn't a free-rider but a true market non-participant, and even that status was reachable by Congress, according to the Court. ${ }^{46}$

$43 \quad 317$ U.S. 111 (1942).

44 Id. at 128 .

45 See, e.g., United States v. Darby, 312 U.S. 100 (1941).

46 At times, PPACA challengers identify the key question to be whether "inactivity is commerce." But the foregoing discussion makes clear that the relevant question is whether "regulate" can include "compel." The purchase of healthcare is undeniably commerce; the issue is whether requiring such commerce is "regulating" it. And if regulation includes compulsionand the evidence adduced above suggests that it certainly can - then the only fallback argument on which challengers can rely is that there is something distinctively wrong with the PPACA's particular mandate. 


\section{Functional/Theoretical Examinations of Distinction}

When we move from particular cases to the larger reasoning asserted in support of an activity requirement, the proffered distinction between congressional regulation of activity and inactivity doesn't appear to fare much better.

One (maybe the) major functional argument asserted by supporters to justify the recognition (I would argue creation) of an activity/inactivity line is a variant on the classic slippery slope metaphor. Such a line is needed, they say, because without it Congress could do anything it wanted, and the concept of limited, enumerated powers and the Tenth Amendment would go by the boards. As Randy Barnett has put things: in the absence of such a distinction,

Congress can mandate individuals do virtually anything at all on the grounds that the failure to engage in economic activity substantially affects interstate commerce. Therefore, [a theory that permits the healthcare law] would effectively obliterate, once and for all, the enumerated powers scheme that even the New Deal Court did not abandon. ${ }^{47}$

I well understand the felt need for some tool for the courts to keep Congress within some finite bounds. As I have written elsewhere, ${ }^{48}$ I do not think the so-called "political safeguards" argument advanced by the Court in Garcia v. San Antonio Metropolitan Transit Authority $^{49}$ - to the effect that states do not need judicial protection because state government has adequate leverage over the federal government due to the role state governmental actors play in the selection of federal officials - works in today's world. Nor do I agree with Justice Breyer's dissenting argument in Morrison that, given changes in the world, it would be constitutionally unproblematic to say Congress should be able to reach any conduct no matter where it takes place and no matter how remote the effect it has on interstate economic markets. ${ }^{50}$

47 Randy E. Barnett, Commandeering the People: Why the Individual Health Insurance Mandate is Unconstitutional, 5 N.Y.U. J.L. \& LIBERTY 581, 607 (2010).

48 See Vikram David Amar, Some Questions and Answers Concerning Justice Blackmun in Federalism and Separation of Powers, 26 HASTINGS CONST. L.Q. 153, 158 (1998).

49469 U.S. 528 (1985).

50 United States v. Morrison, 529 U.S. 598, 660 (2000) (Breyer, J., joined by Stevens, Souter and Ginsburg, JJ., dissenting). I should add, though, that even as courts play a useful role, a meaningful answer to the slippery-slope problem relies heavily on political common sense - the notion that many far-fetched laws would never be adopted in the world we know. For instance, challengers to the healthcare Act are fond of saying that if Congress can require healthcare, it can require that we all eat broccoli. But under current doctrine (and even embracing the socalled activity requirement healthcare challengers offer), Congress could undeniably prohibit the eating (and production, sale and distribution) of all broccoli. The unlikely prospect of Congress 
But while I think courts should not abdicate a robust role in policing the boundaries of federalism, I think the tools judges should use must be of the right shape and size for the job. The activity/inactivity device is inapt because it is neither required, nor particularly useful, in separating the permissible from the impermissible exercises of congressional authority.

The activity/inactivity line can't be absolutely necessary (as its proponents seem to claim) to prevent Congress from having boundless power, because Lopez and Morrison conclusively demonstrate that the Court can say "no" to Congress even where activity is involved. In other words, there is no question but that the activity requirement was satisfied in Morrison, and yet the Court still struck the Violence Against Women Act down on the (more plausible) ground that the regulated activity was not sufficiently connected to commerce. $^{51}$ In other words, the result and analysis in Morrison conclusively demonstrated that there are tools other than the activity/inactivity line that allow the courts to police Congress.

Of course, additional tools are welcome where they are helpful to the task involved. But just as the activity/inactivity line is not required, neither is it remotely sufficient. Consider, for example, a Congressional law that requires young persons to show up for military service. So far, so good - Congress' power to raise and support military troops has been understood to justify the draft. ${ }^{52}$ As discussed above, that breach of the activity/inactivity line is difficult enough for healthcare challengers to explain away. But imagine further that Congress mandates that the men and women who might be drafted must procure health insurance because the government wants to make sure its future draftees are fit and ready for action right away. If required health insurance is permissible under this reasoning, then the challenge to the PPACA disappears because, of course, Congress is entitled to use not just the Commerce Clause but rather all powers within its enumerated panoply. And if required healthcare is not justifiable under the power to raise armies, that result certainly is not because of any activity/inactivity distinction; the draft itself obliterates that line. Instead, it is because the relationship between raising armies and required healthcare is too strained.

Or imagine further that Congress mandated that all persons eat at least two servings of green vegetables and exercise vigorously for at

prohibiting broccoli consumption doesn't keep us up at night; the equally unlikely prospect of Congress mandating such consumption needn't either.

51 Id. at 613 ("Gender-motivated crimes of violence are not, in any sense of the phrase, economic activity.").

52 See supra note 18. 
least half an hour per day on the theory that potential military troops need to be well nourished and healthy. And so forth. If Congress is to be reined in from requiring whatever it might dream up - that is, if Congress is to be prohibited from doing anything and everything it might want - the limit cannot be found in any activity/inactivity line, but rather some notion that there must be a proximate nexus between the power Congress is given in the Constitution and the means Congress has chosen to implement that power. Notions of proximate relationship - a limit on attenuation, if you will - make some sense and probably do a good job of explaining the results in cases like Lopez and Morrison. But if requirements of proximity and limits on attenuation are needed and sensible, they demonstrate that the proffered activity/inactivity line isn't doing, and really can't do, the work.

To paraphrase Justice Blackmun in Garcia, the proffered test between activity and inactivity is not just "unworkable in practice" but also "unsound in principle." 53

None of this is to say that all congressional mandates are constitutionally permissible so long as they advance some otherwise legitimate federal goal. The Constitution itself, in some of its provisions and doctrines, prevents Congress from coercing certain kinds of action. As Professor Magliocca points out, for example, the Third Amendment prohibits the quartering of troops in private homes during peacetime, the Fifth Amendment prevents government from mandating self-incrimination and the surrender of property without just compensation, ${ }^{54}$ the First Amendment prohibits government from mandating that individuals be vessels for government speech, ${ }^{55}$ and the Supreme Court has held in the so-called anti-commandeering cases, New York v. United States ${ }^{56}$ and Printz v. United States, ${ }^{57}$ that federalism principles prohibit Congress from mandating that state governments exercise their regulatory power on behalf of federal goals. On the other hand, as pointed out earlier, the federal government can mandate taxes, and jury and military service, among others, even if the individuals so mandated are doing nothing other than being.

The question then becomes: when is a mandate that would in fact promote a legitimate end nonetheless constitutionally problematic? Although no simple line can be drawn to connect all the dots, it is noteworthy that with respect to those mandates that are acknowledged to be constitutionally impermissible, the individual or entity

\footnotetext{
Garcia v. San Antonio Metro. Trans. Auth., 469 U.S. 528, 546 (1985).

See Magliocca, supra note 35.

See, e.g., Wooley v. Maynard, 430 U.S. 705, 706 (1977).

505 U.S. 144, 188 (1992).

521 U.S. 898, 935 (1997).
} 
being mandated is not contributing to the problem Congress is trying to solve in any distinctive way or in a way that explains the extent of the mandate. For example, in the anti-commandeering cases, the states that were commandeered were themselves not in any way standing as an obstacle to Congress' ability to otherwise implement its regulatory objectives. ${ }^{58}$ They were, simply put, not part of the problem Congress was trying to fix, but instead had simply declined to be the solution Congress wanted them to be.

So too for the ban on quartering and the ban on compelled speech. In those instances, Congress might prefer that the individuals being mandated assist Congress with its goals, but the mere existence of these individuals does not create the problem (the need for troop accommodations, or the need for governmental speech) to which Congress is reacting, or at least it does not create the kind of problem that would explain a focused mandate on those persons in particular. Instead, government could be said to be using the mandated persons as its own instruments for the accomplishment of an objective not particularly related to those individuals, except in the sense that they are convenient implements. Even in the takings context, as Professor Jed Rubenfeld has creatively and powerfully argued, when the government is not "using" private property for its own ends, but rather is preventing the private property owner from exporting externalities to other people, a taking that triggers a requirement of just compensation is less likely to be found. ${ }^{59}$

On the other hand, military defense, government spending (on roads and other infrastructure), and a system of criminal and civil justice requiring juries - these are all "public goods" in the sense that people benefit from them and have an incentive to be free riders unless mandated to contribute. The free riding is itself a big part of the problem Congress is trying to solve. So long as the mandate is "congruent and proportional" (to borrow from another federalism context $)^{60}$ to the free-rider problem that the very existence of the individuals being mandated is creating, then the mandate seems less objectionable. This explains why, for example, quartering of troops is different from the draft. A narrow, focused, and selective mandate on a

58 In New York, the State that was conscripted was not producing or disposing of any of the problematic radioactive waste, but rather simply declining to regulate it, and in Printz, the local law enforcement officers who were improperly commandeered were not contributing to the proliferation of handguns but were merely handy personnel the federal government thought it could use to perform federal background checks.

59 See Jed Rubenfeld, Usings, 102 YALE L.J. 1077 (1993).

60 See City of Boerne v. Flores, 521 U.S. 507, 508 (1997) (requiring congruence and proportionality with respect to congressional exercise of power under Section Five of the Fourteenth Amendment). 
few homeowners to bear the costs of a military that everyone benefits from is not a proportionate response to a free-rider problem in the way that a random and broad-based draft that seeks sacrifice from thousands, if not millions, of people is.

When viewed through this prism, the healthcare mandate would seem to fall on the permissible side of any implicit constitutional line safeguarding against instrumentalization. As noted earlier, the mandate is a response to the free-rider problem, a problem that itself is exacerbated by other undoubtedly permissible elements of the healthcare reform package. The individuals mandated are - if not subject to the mandate - part of the problem, rather than merely being a convenient part of a solution to problems created by other folks.

When we pull the focus back from the mandate provision in particular, and ask - from the perspective of the Commerce Clause in general or the Commerce Clause cases in particular - whether the healthcare law is the kind of law we might envision Congress enacting under its powers to regulate "commerce among the several states," the challenge to PPACA seems somewhat improbable. Healthcare is, as everyone concedes, a huge and rapidly growing part of the national economy, and the part of the national economy that is creating hugely daunting challenges to economic and fiscal health more generally. And there doesn't seem to be a real question that Congress is regulating healthcare at least in significant part because of its economic centrality and the spiraling costs that affect the rest of the country's economic future. This Act bears almost no big-picture resemblance to either of the only two laws struck down in the last 70 years as being beyond Congress' Commerce Clause powers - the Gun Free Schools Zone Act, and the Violence Against Women Act. To the extent that Justice Souter was even remotely correct in his dissent in Morrison that Lopez and Morrison created a doctrinal "cousin to the intentbased analysis employed in Hammer $v$. Dagnehart, but rejected in United States v. Heart of Atlanta and United States v. Darby," ${ }^{61}$ Lopez and Morrison look very little like the present challenges to healthcare. In the PPACA, Congress is openly and notoriously regulating markets, incentives created by markets, and the distributions of commodities that result from those markets.

I should add that I think a "cousin to [an] intent-based analysis" to limit Congress' use of the Commerce Clause would not be an illegitimate device to employ. Justice Souter was correct that any intentbased inquiry was flatly rejected in the cases from the 1960 s evaluat-

61 Morrison, 529 U.S. 598, 643 (2000) (Souter, J., joined by Stevens, Ginsburg and Breyer, JJ., dissenting). 
ing civil rights anti-discrimination laws, but what he forgot to mention was that this rejection was itself flatly inconsistent with the Court's famous admonition in McCulloch that, "[s]hould Congress, under the pretext of exercising its powers, pass laws for the accomplishments of objects not entrusted to the government, it would become the painful duty of [the Supreme Court], should a case requiring such a decision come before it, to say that such an act was not the law of the land." ${ }^{22}$ The statutes in Lopez and Morrison were arguably pretextual in this way - as far as Commerce powers are concerned - and thus may be correctly decided under a reclamation of the majestic McCulloch framework.

\section{Doctrinal Examination of Other Powers}

Although most of my thinking on the healthcare litigations concerns Congress' Commerce Clause powers, I offer a few observations on two other plausible grounds for upholding the law - the Necessary and Proper Clause, and the taxation power. With respect to the socalled sweeping (Necessary and Proper) clause, both Justice Scalia's concurrence in Raich and Justice Breyer's somewhat broadly written opinion for the Court in United States v. Comstock ${ }^{63}$ support Congress' power to create the mandate even if the Commerce Clause jurisprudence, standing alone, did not. Whether simply "being" is economic activity, and whether Congress is ordinarily limited to regulating economic activity under the Commerce Clause, the mandate is a necessary and proper entailment of Congress' regulation of the healthcare insurance industry. As noted earlier, by prohibiting the insurers from discriminating against persons with so-called preexisting conditions, Congress has exacerbated the free-rider incentive problem to which the mandate is a plausible response. If regulation of all marijuana possession was necessary and proper to prevent some marijuana from leaching into the interstate (black) market for drug sales - as Justice Scalia reasoned in Raich - then so too imposing the mandate is necessary and proper to making the ban on preexisting-condition discrimination workable in the healthcare law. Nor can it possibly matter that the problem that Congress is responding to in the mandate was made worse by Congress' own (permissible) regulation of the insurance industry ${ }^{64}$ In Comstock, the Court relied on the fact that Congress arguably made the problem of dealing with sexually deviant ex-felons worse by incarcerating them under valid federal criminal laws as a

62 McCulloch v. Maryland, 17 U.S. (4 Wheat.) 316, 423 (1819).

63130 S. Ct. 1949 (2010).

64 District Court Judge Vinson in Florida clearly erred in suggesting otherwise. 
reason supporting, rather than undermining, Congress' power to civilly detain them when states were disinclined to deal with them. ${ }^{65}$

As to whether the mandate can be upheld as a tax, I find at least some of the arguments advanced by the healthcare Act challengers to be problematic. The fact that Congress didn't affirmatively point to the power to levy taxes (the way it did the power to regulate commerce) cannot be a reason why the mandate cannot be upheld as a tax. Nor can the fact that at various points in the law Congress referred to the payment to the federal Treasury as a penalty. If the mandated payments operate the way taxes operate - by raising revenues to defray costs of providing services to a large class of persons then the fact that Congress didn't label them as taxes shouldn't resolve the question of whether Congress had the power to levy them. ${ }^{66}$ Nor should the fact that Congress didn't list the mandate provision among those measures that would raise revenues; if in fact the mandate does raise revenues the way a tax does, then whether Congress anticipated that or not should not defeat congressional power. And if the political debate made clear to all citizens that the mandate would be imposed else they would pay money to the federal treasury - that is, the monetary implications for individuals were clear to all what is the point of insisting that people in Washington, D.C. use the "T" word in the congressional debates?

Another interesting question presented by the tax aspect of these challenges might arise if the federal government, for political reasons, fails to assert tax power as a plausible foundation for the PPACA. Could a court nonetheless uphold the statute on that ground, or is the precise basis of federal legislative power a waivable matter?

\section{The LARger Political AtMosphere}

I close by noting yet another couple of oddities about the healthcare challenge. The plaintiffs seem to concede that a single-payer scheme by which the federal government provides health insurance to all and mandates that we all pay into a fund to receive such services would be constitutionally permissible. Single-payer schemes and the extension of Medicare to all persons seem to be options that are accepted as constitutionally permissible. In terms of the federalism values served by the Tenth Amendment, why would a scheme that preserves more leeway for state and individual choice be less permissible? Again, sometimes making Congress go through certain hurdles will

65 See 130 S. Ct. 1949 (2010).

66 But cf. Clinton v. New York, 524 U.S. 417, 469 (1998) (Scalia, J., dissenting) ("[T]he title of the Line Item Veto Act ... has succeeded in faking out the Supreme Court.”). 
focus attention politically in a way that serves federalism values, but in the present case, no one seems unaware of the breadth of what Congress was doing and why it was doing it. As a technical, logical matter, the greater power does not always subsume the lesser one. But we need an explanation for why the Constitution would prohibit something for a set of reasons that are implicated even more directly by something the Constitution permits. The Constitution may be imperfect, but we should not construe its limitations as being arbitrary and unreasoned absent text that gives us no choice.

As to what will happen to these litigations as they move up the appellate ladder, I am not inclined to predict. I will say that the district court opinions invalidating the measure mean, as a legal matter, very little. On questions of pure law, district court opinions are little more than placeholders. And district judges can get away with saying a lot of stupid things, both because what they say as to the law doesn't usually matter much, and because there is no dissent filed at the same time as their opinion pointing out the weaknesses in their reasoning. That is not true at the Court of Appeals level, which is obviously a much more important forum. When we move outside of the judicial arena to the academy, it is noteworthy that to date very few of the top-tier conservative constitutional analysts at the nation's top twenty-five, or so, law schools seem to be willing to say on the record that they think the challenge should prevail. But cases like this build in momentum, and in that respect, the lower court rulings may matter a lot in the real world as people become more willing to climb onto the bandwagon.

If and when the vehicle arrives at the Supreme Court, it's hard to count many noses against the statute at present. Justice Thomas, perhaps. But beyond that, it's difficult to see any sure votes to invalidate. And to win, the challengers will most likely have to persuade Justice Kennedy. That might be a tall order. In addition to being sensitive to important nationalist issues, ${ }^{67}$ (and in this regard, I should say I think neither the Gun-Free Schools Zones Act nor the Violence Against Women Act involved the kind of nationalist issue presented here), Justice Kennedy has a knack for being on the right side of history. And does anyone doubt that the healthcare law, or something very much like it (if not more aggressive) is inevitable in America as the next generation grapples with spiraling healthcare costs?

Finally, this does not seem to be the kind of dispute that the Court needs to resolve for fear that the political process is inattentive

67 See, e.g., United States Term Limits, Inc. v. Thornton, 514 U.S. 779, 838 (1995) (Kennedy, J., concurring). 
or otherwise incapable of error correction. Two elections (2008 and 2010) were fought largely over this measure, and a third election (2012) will feature the law prominently for the people's approval or rejection. To the extent that the Court feels more justified in intervening when the channels of political change are clogged or polluted, this does not appear to be such an instance. 